\title{
The Relationship Between Audit Committee Characteristics and Financial Performance of Listed Banks in Ghana
}

\author{
Joseph Kwasi Agyemang \\ Department of Accounting and Finance, Faculty of Commerce, University of Eswatini, Eswatini
}

\begin{abstract}
This study presented a description of the performance of eight banks listed on the Ghana stock exchange using return on equity and return on asset as performance indicators. It also presented aggregate information on the performance of these eight banks over a five-year period. It further analyzed the association between performance and audit committee size, independence, audit committee members' expertise and experience and gender diversity of the audit committee. Audit committee size and the expertise and experience of audit committee members was found to be positively correlated with return on equity. However, the independence of the audit committee members and gender diversity of the committee had a negative correlation with return on equity. Similarly, audit committee size and the expertise and experience of audit committee members correlated positively with return on asset. However, audit committee independence and gender diversity had a negative correlation with return on asset. This means in response to the hypothesis; ROE is positively related to audit size and the audit members' expertise and experience but negatively related to audit committee independence and gender diversity of the audit committee. Similarly, ROA is positively related to audit size and the audit members' expertise and experience but negatively related to audit committee independence and gender diversity of the audit committee.
\end{abstract}

Keywords: Audit committee, Return on Assets, Return on Equity, Financial Performance

DOI: $10.7176 /$ RJFA/11-10-03

Publication date:May $31^{\text {st }} 2020$

\subsection{Background of the Study}

One of the best corporate governance practices that has received the attention of financial policy-makers and researchers in recent years is auditing. Auditing is inclusive of the management and financial tools used by organizations to monitor top management in order to safeguard owners' and stakeholders' investments as well as to attract more foreign investments (Ghazali, 2010; Rustam et al., 2013). In other words, it is widely claimed that the monitoring role of audit committees is a key element in corporate governance which helps to control and monitor managers' practices (Campbell \& Mínguez-Vera 2008; Afify, 2009). It is also believed that audit committees can improve the quality of financial reporting and decrease audit risk, thereby improving the quality of reported earnings (Contessotto \& Moroney 2014; Abernathy et al. 2015).

These claims mean that auditing and audit committees play an important role in overseeing and monitoring a company's management, with the aim of safeguarding the interests and investments of the owners (Kallamu \& Saat 2015). One primary role and responsibility of audit committees is to make recommendations on the appointment and change of external auditor. The role covers wider areas including the monitoring of managers and review of the company's internal control system (DeZoort et al. 2002; Aldamen et al. 2012).

Central to the effectiveness of audit committee are audit characteristics such as size of the audit committee, independence, expertise or knowledge of audit committee members. It has widely been argued that the quality of such audit committee characteristics help enhance the effectiveness of the audit committee which in turn has a significant positive impact on the performance of the organization (Carcello \& Neal, 2000; Abbott et al., 2003; Rustam \& Zaman, 2013).

Following the assumption that audit committee characteristics have significant impact on organizational performance, several studies have been done and continue to be done to empirically assess the impact (e.g. Aldamen et al., 2012; Dellaportas et al., 2012; Amer et al., 2014; Al-Matari 2013; Kallamu \& Saat, 2015; Herdjiono \& Sari, 2017). Though the relationship is significant, while some studies have found a positive relationship between audit committee characteristics and organizational performance, others have not. Thus, the relationship is still ambiguous and attracts the interest of more researchers.

Moreover, in the Ghanaian context few of studies have been done to analyze specific audit committee characteristics and the performance of financial institutions including banks (Glover-Akpey, 2016). This calls for more investigations to clearly establish the impact of audit committee characteristics on the performance of banks in Ghana.

The need to assess the impact of audit committee characteristics such as size of the committee, independence, expertise, and meetings of the committee, on the performance of banks in Ghana cannot be overemphasized. This is necessitated from the importance of corporate governance and the results of several studies done across the globe on the relationship between audit committee characteristics and organizational performance. The results of such a study would be a useful source of information for national financial policy-makers, executive boards, 
stakeholders of financial institutions and institutions under study for decision making towards organizational performance.

Given this background, it was considered necessary to conduct this study to gather and analyse data to understand and appreciate the role of auditing in the performance of listed banks in Ghana.

The conduct of top management if not properly monitored can lead to loss of owners' and stakeholders' investment. Without effective auditing to monitor managers' practices, organizations stand a high risk of losing investments (Campbell \& Mínguez-Vera 2008; Afify 2009; Ghazali 2010).

The recent poor performance and collapse of several banks such as UT Bank and Capital Bank in Ghana call for serious auditing committees to monitor management and provide proper financial reporting. Some observations about the poor performance of several banks in Ghana of late are that the banks have weak capacity to perform crucial financial reporting systems due to poor auditing. Glover-Akpey (2016) observed that fraudulent financial reporting has increased among the banking institutions in Ghana and this has made stakeholders at all level to become astounded.

It is believed that fraudulent financial reporting could be corrected or minimized by employing an effective audit committee (Rustam \& Zaman, 2013). This is because it is in the best interests of audit committee activities to exercise influence over the financial resources available to the internal audit function.

Also, it is widely argued that the quality of the audit committee characteristics determines the effectiveness of the audit committee which in turn positively impact the performance of the organization (Carcello \& Neal, 2000; Abbott et al., 2003; Rustam \& Zaman, 2013). Thus, this study seeks to assess the impact of audit committee characteristics on the performance of listed banks on the Ghana Stock Exchange (GSE).

\subsection{Objectives of the study}

The main object of this study is to assess the effect of audit committee characteristics on the performance of listed banks on the Ghana Stock Exchange (GSE). Specific objectives of the study are:

i. To establish the relationship between audit committee size and financial performance of listed banks in Ghana. ii. To establish the relationship between audit committee independence and financial performance of listed banks in Ghana.

iii. To establish the relationship between audit committee expertise and experience and financial performance of listed banks in Ghana.

iv. To establish the relationship between gender diversity of audit committee and financial performance of listed banks in Ghana.

\subsection{Research Questions}

This study is guided by the following questions:

i. What is the relationship between size of the audit committee and performance of listed banks on GSE?

ii. What is the relationship between the independence of the audit committee and performance of listed banks on GSE?

iii. What is the relationship between audit committee members' expertise and experience on performance of listed banks on GSE?

iv. What is the relationship between gender diversity of audit committee and performance of listed banks on GSE?

\subsection{Literature review}

\subsubsection{Review of theories}

Several organizational theories explain and support the basis or need for establishing audit committee in corporate organizations. These theories include Agency Theory, Resource-based Theory, Institutional Theory, Systems Theory, and Transaction Cost Economics Theory.

\subsubsection{Agency Theory}

Agency Theory is a supposition that explains the relationship between principals and agents in business. It is concerned with resolving problems that can exist in agency relationships between principals (i.e. shareholders) and agents of the principals (e.g. company executives).

The Agency Theory was propounded by Ross and Barry (1970) who described an organization as important structure through which, it is likely to apply relevant ideologies such as audit committees. This idea depends on the relationship between agents and their principals which is reinforced by the principal (manager) of an organization recruiting professionals to monitor the agent (Adams, 1994). The theory explains that moral hazards and unfavorable selection of alternative programs influence the output of the agent (Abdel-Khalik, 1993). The agency theory further explains that organizations have economic incentives to report on any relevant program that seeks to improve performance (Deumes \& Knechel, 2008; Channar et al., 2015).

Agency theorists argue that corporate governance should lead to higher stock prices or better long-term performance, because managers are better supervised and agency cost are lower. Yet, according to (Gompers, Ishii 
\& Metrick, 2003), the evidence of a positive association between corporate governance and firm performance may have little to do with the agency explanation. Whilst some studies (Weisback, 1988; Rosenstein \& Wyatt, 1997; Mehran, 1995; and John \& Senbet, 1998) find better performance for firms with boards of directors dominated by outsiders, other studies (Weir \& Liang, 2001; Pinteris, 2002) find no such relationship in terms of accounting profit or firm value. Besides, Forsberg, (1989) found no relationship between the proportion of outside directors and various performance measures.

\subsubsection{Resource-Based Theory}

Penrose (1959) provides theoretical basis of the resource-based theory where the organization was seen as managerial firm and the gathering of internal resources that have significant effects on the firm's strategies, efficiency and performance. The theory is an economic model that are adopted and used by organization to decide the available strategic resources in the organization. The focus of the theory is the basis for competitive advantage of the organization which lies mainly in the application of the packaged resources at the disposal of the firm. Therefore, in order to transform a short-run competitive advantage into a sustained competitive advantage, there is the need to have heterogeneous resources which are not completely mobile (Preuss, 2013). In a more efficient manner, this converts into priceless resources that are neither absolutely imitable nor substitutable without great effort (Preuss, 2013).

The theory focused on some key important areas namely firm attributes and information, assets abilities of the firm and the acquisition of knowledge by employees and management. These identified valuable resources are managed by the organization which help them to implement strategies or measures that enhances efficiency and effectiveness (Miles, 2010). The resource-based theory explains that the valuable resources acquired by the firm lead to a competitive advantage. This means that the valuable resources are completely controlled by the organization to improve its contribution to achieving competitive advantage in its industrial context (Hoffman and Sandelands, 2005). Islam and Siwar (2013) mentioned that the environmental situation of a firm can influence the sustainable competitive advantage of the firm. They argued that organizations that manage the environmental factors can generate more sustainable competitive advantage towards employee efficiency (Li and Geiser, 2009).

According to Hindle (2005) a competitive advantage changes into assets in conditions that an organization is able to apply resources in the competitive environment. This indicates that organizations are to examine their internally resources using conditions such as scarcity, imitability and value (Koszewska, 2004). The condition of value explains the opportunities available for the firm to exploit to improve performance. The scarcity of rarity is the resources managed by the organization's competitors. The imitability condition is where the organization acquires few resources and is likely to lose cost advantages compared to other competitors (Hindle, 2005).

\subsubsection{Institutional Theory}

Institutional Theory provides a theoretical lens through which researchers can identify and examine influences that promote survival and legitimacy of organizational practices (Glover, 2014). The factors include culture, social environment, the legal environment, tradition and history, and economic incentives, whilst acknowledging that resources are also important (Baumol, 2009).

The theory emphasizes on legitimacy which indicates that the adoption of sustainable practices be seen by stakeholders as being proper and appropriate (Brunton, 2010). Institutional Theory is traditionally concerned with how groups and organizations better secure their positions and legitimacy by conforming to the rules (such as regulatory structures, governmental agencies, laws, courts, professions, and scripts and other societal and cultural practices that exert conformance pressures) and norms of the institutional environment (Scott, 2007). Therefore, institutions can define what is appropriate or legitimate and thus render other actions unacceptable or even beyond consideration (Tate et al., 2010). This will then affect how organizations make decisions.

Institutional Theory can be used to explain how changes in social values, technological advancements, and regulations affect decisions regarding sustainable activities and environmental management (Ball, 2010). It explains how different organizational strategies lead to the adoption of environmental management practices (Tate et al., 2010). It is this that can provide insights into the role of different actors towards audit committee program and their role in the achieving conformity. Hence, the institutional perspective allows for the focus on the role of conformity, regulatory and social pressures in driving organizational actions (Glover, 2014). This theory can be used to explain how changes in social values, technological advancements, and regulations affect decisions regarding sustainable activities (Ball, 2010).

\subsubsection{Systems Theory}

Systems theory views organization as complex set of dynamically intertwined and interconnected elements, including its inputs, process, outputs, feedback loops and the environment which it operates. Brammer and Walker (2007) mentioned organization act as systems interacting with their environment, any equilibrium is constantly changing as the organization adapts to its changing environment. Systems theory describes the interrelatedness of all parts of an organization and how one change in one area can affect multiple other parts (Li and Geiser, 2009).

Organizations are viewed as open systems, continually interacting with their environment. They are in a state of dynamic equilibrium as they adapt to environmental changes. The foundation of systems theory is that all the 
components of an organization are interrelated, and that changing one variable might impact many others (Maignan, 2012). According to Lozano and Valles (2013) system theory views organizational structure as the established pattern of relationships among the parts of the organization, of particular importance are the patterns in relationships and duties. These include themes; of integration (the way activities are coordinated), differentiation (the way tasks are divided), the structure of the hierarchical relationships (authority systems), and the formalized policies, procedures, and controls that guide the organization (administrative systems) (Maignan, 2012).

The relationship between an organization and its environment is characterized by a two-way flow of information and energy (Marron, 2013). Most organizations attempt to influence their environment. Menon (2013) expressed that the relationship between the environment and organizational structure is especially important. Organizations are open systems and depend on their environment for support. Kumar (2012) stated that senior management support plays a pivotal role in the institutionalization of responsible behavior. This theory provides the basis for the role of changes in organizational structure in the implementation of audit committee programs which is associated with audit fees.

\subsubsection{Transaction Cost Economics Theory}

The Transaction Cost Theory had its origin in the institutional economics, formulated by Coase (1937) to explain three areas of transaction costs. These costs include the cost of using the price mechanism, the costs involved in bargaining and finishing a detach for each swap over contract that happens in the market and the costs of unveiling the applicable prices. Williamson (1985) expanded the original transaction cost economies theory by Coase (1937) and identified two types of costs namely direct and secondary costs. On one hand, the secondary costs are linked to the cost of spending from the decisions and regulations of the government of a nation. On the other hand, the direct costs are the expenditures from management relations. Williamson (1985) further identified five transaction costs which include monitoring cost, cost of enforcement, and cost of negotiation, cost of searching or research and contracting costs.

Further, the transaction Cost Economics Theory portrays the situation for an organization to control an economic exchange both internally and externally with the motive of improving efficiency and performance (Williamson, 2008). In transaction cost economics, the aim of the organization is to reduce the total costs of production and transaction. It answers queries about why the organization operates or exists in the first place? It also answers the questions on how do organizations define their boundaries and how they decided to govern their operations (Kumar, 2012; Williamson, 2008).

Brammer and Walker (2007) explained that transaction costs are useful for analyzing issues that involve selecting the best out of the many that could improve the efficiency and performance of the business. This is because the cost component of the decisions or strategies to be carried out by the firm has to be discussed before conclusion can be made (Brammer and Walker, 2007). According to Tate et al. (2011) the transaction cost can be understood when related to the competitive bidding process which determines effective means of determining the lowest cost of taking decisions on who should be chosen to perform audit of firms. In the decision process and from the basic economic model, the higher the costs involved in the transaction or business the less it is likely for the organization to make a final conclusion (Tate et al. 2011).

\subsubsection{Relevance of the Theories to the Study}

From the above theories, it can be understood that firms listed on the Ghana Stock Exchange (GSE) is to provide financial and non-financial services to the public and also earn enough to make them financially sustainable. The performance of the firms however depends on how successful management is in adapting to the changing circumstances. The ability to quickly and properly react to changes in the business environment characterize the quality of the company's management. The maximization of firm's wealth is influenced by two main factors namely, internal and external factors. The external factors are the external influences that are beyond the control of management in the institution. The internal factors emanate from inside the institution and encapsulate the ability of management to develop and implement planning strategies that fit the business to the environment (Channar et al., 2015). The agency theory is relevant to this study because audit committee is one of the many mechanisms used internally by firms to improve its performance. It helps to examine the interactions between the administrators and workers to ensure effective implementation of audit committee programs that would benefit the institution.

The agency theory, system theory, institutional theory, resource-based theory and transaction theory presented above refer to how researchers develop thoughts to answer a question. The thought are clustered into themes that frame the subject of discussion (Telewa, 2014) such as audit committee programs in relation to firm's performance. This study investigates the effects of audit committee and audit fees on the performance of banks and non-banking institutions in Ghana which can be understood by the institutional, resource-based, systems and transaction cost economics theories which are also linked to the research objectives indicated in chapter one of this study.

The resource-based theory basically explains the available resources used by an organization to improve their effectiveness and efficiency (Miles, 2010). The ability of management of the banking and non-banking institutions 
to implement effective audit committee depends on the available resources. This is as a result of the fact that audit committee attracts audit fees for auditors. The institutional theory explains the theoretical lens through which academicians or researchers can identify and assess influences that inhibit or promote the efficiency and survival of organizations (Gatari, 2014). The institutional structure has influence of the ability of the firm to conduct frequent audit committees. In relation to this Hay et al., (2008) and Vafeas and Waeglein (2007) mentioned that the effect of audit fees and audit committee on performance depends on total assets (firm size) of the business, age of the firm, profitability and other features of audited entity which can be classified as institutional structure. The system theory gives an overview of the interrelatedness of all the components of an organization and how changes in one component influence others towards achieving efficiency ( $\mathrm{Li}$ and Geiser, 2009). To achieve efficient audit committee in a firm it requires coordination among members of the committee.

The transaction cost economies theory provides the basis for understanding the relationship between audit committee and firm performance. The theory provides a diagnostic structure for organizations to understand conditions where audit committee can generate benefits for a firm. The transaction cost economics theory explains measures to be taken by organizations to reduce audit fees or costs associated to the activities of the audit committees. From the theories indicated above, it can be deduced that an institution is influenced by many diverse factors that determine its capacity to conduct effective and frequent audit committee activities.

\subsection{Empirical review}

\subsubsection{Audit committee: Definition and background}

To begin with, audit committee (AC) is an important corporate governance tool that has been emphasized in the literature and principles of corporate governance. It is considered a necessary tool for effective corporate governance in any organization that aims to align the interests of management and shareholders, and also enhance transparency in the organization.

There are several definitions of the concept of audit committee that help to explain and understand the concept. For example, in the words of Collier (1993); Verschoor (2008); Rezaee (2009); and Arens et al. (2014) respectively, audit committee is:

"The existence of a subcommittee of the main board comprised mostly of non-executive or independent directors with responsibility for oversight of auditing activities" (Collier, 1993).

A standing committee of the board of directors organized under the by-laws of the corporation. Duties of the committee are prescribed by statute, regulation, and best business practice. They involve oversight of financial reporting, auditing, ethics and compliance, and risk management processes" (Verschoor, 2008).

A committee composed of independent, non-executive directors charged with oversight functions of ensuring responsible Corporate Governance, a reliable financial reporting process, an effective internal control structure, a credible audit function, an informed whistleblower complaint process and an appropriate code of business ethics with the purpose of creating long-term shareholder value while protecting the interests of other stakeholders" (Rezaee, 2009).

A selected number of members of a company's board of directors whose responsibilities include helping auditors remain independent of management" Arens et al. (2014).

From these and other definitions, it can be seen that an audit committee is a corporate governance tool that uses non-executive directors as a means of control and oversight over several managerial roles such as internal auditing, risk management, compliance, and financial reporting. For an audit committee to effectively operate and achieve its goals, it members have to be independent of the executive management.

Many institutions and agencies have looked at audit committee functioning as a way of providing active supervision of the financial reporting process and also ensure monitoring of the relationship between management of the firm and its external auditor. The institutions and agencies include the National Association of Corporate Directors, Securities and Exchange Commission and the Public Oversight Board (Abbott et al. 2003). This therefore indicates that audit committee play crucial role in determining audit fees (Naser et al. 2007; Mitra et al., 2007).

The responsibility of audit committee is to hire the services of audit consultants and compensate the auditors to perform better to improve business performance. Apart from this role, it also frequently reviews the committee charter and present reports to the board of directors. In addition, the audit committee handles disputes with auditors and communicates those issues with management, audit units and both internal and external auditors. Though these responsibilities are observed, the core task of the audit committee is to provide an oversight on the reliability of financial reporting. That is, the committee conducts review of quality of financial statements by reading the execution and changes in relation to accounting principles (Abbott et al. 2003).

Soliman and Ragab (2014) argue that firms without audit committees or firms with weak committees usually demonstrate earnings overstatements by prior period adjustments and fraudulent financial reporting. Rustam et al. (2013) mentioned that good governance portrays that membership of audit committee should have important and competencies which include financial experience, independences and literacy as well as leadership, time 
management and strategic thinking.

It is noted that establishing audit committee in the corporation began to increasingly receive the attention of the public after the publication of a report by Blue Ribbon Committee (BRC, 1999). The committee's report gives suggestions on the size, composition and activities of audit committees that are intended to support external auditors and to improve the quality of internal monitoring. The report also emphasizes the relevance of improving the effectiveness of corporate audit committees and new regulations linked to the functioning of audit committee. Consequently, new rules were developed that demanded the disclosure of audit committee composition, charter and activities in company's proxy statements (SEC, 1999). The introduction of this rule has required auditors to focus on numerous factors which include audit fees, audit committee independence and audit risks. According to Rustam et al. (2013) audit committee members encourage management of a firm to appoint auditors with the required and satisfactory knowledge and with higher reputation. The management of the firm also require greater audit effort from external auditors.

Baxter and Cotter (2009) highlight that audit committees take three forms of actions to achieve higher audit quality. The first form is to convince management for the selection of an auditor with greater reputation and with in-depth knowledge on auditing. The second action of the audit committee is to require bigger audit efforts from the audit firm or auditors. Third, audit committee through indirect means influence the level of audit coverage by extenuating threats to replace the auditor (Rustam et al. 2013).

Baxter and Cotter (2009) also outlined the benefits of audit committee that it leads to reliable financial reporting, reduces errors, minimizes irregularities and other untrusted reporting systems in the company. Highly functioning audit committees are believed to enhance corporate disclosure practices in many companies across the world (Glover-Akpey, 2016).

To be highly effective it is required that an audit committee maintains clear, vivid, flexible and practical terms of references (Krishnan and Visvanathan, 2006). This is often referred to as the charter for effective and efficient achievement of objectives. The BRC repots mentioned that an effective audit committee should have adequate staffs who are independent and financially literate. The effectiveness of the audit committee depends on the sufficient number of directors on the committee that organize meetings regularly (Krishnan and Visvanathan, 2006).

In Ghana, listing regulations mandate all firms listed on the GSE to establish audit committees. However, it does not provide detailed guidelines on AC effective functioning. For this reason, even though listed firms in Ghana have long been mandated to establish AC, issues on their effective functioning have become popular only in the last decade, following the introduction of the SEC Guidelines in 2002 (Kwakye, Owusu and Bekoe, 2018).

A more detailed guideline on AC functioning was introduced and recommended by SEC in 2002 to encourage best corporate governance practices. The SEC Guidelines are based on the principles outlined by the Organization for Economic Co-operation and Development (OECD), the Commonwealth Association for Corporate Governance and codes of CG issued by regulatory authorities in emerging markets. The SEC Guidelines provide, among others, that ACs of these companies be made up of at least three (3) members, dominated by non-executive directors (NED), and should have at least an accounting or finance expert(s) on the committee. It also includes other roles relating to audit quality, risk assessment and reporting of activities. Although AC composition, functions, authority and reports are enshrined in the SEC Guidelines, it appears not to be as comprehensive as those of developed economies (Kwakye, Owusu and Bekoe, 2018).

Some studies found that stakeholders of corporations do not attach the same level of importance to the roles, responsibilities and characteristics of AC, perhaps because the acceptance of AC system and its practical operation is still emerging in Ghana (Assenso-Okofo et al., 2011; Aboagye-Otchere, 2012).

\subsection{Overview of Audit Committee Characteristics}

This study analyses the relationship between the availability and effectiveness of several audit committee characteristics and the performance of listed banks on the GSE. These characteristics are size of the committee, independence of the committee, experience or expertise of committee members, gender diversity, and frequency of meetings defined as follows:

\subsubsection{Size of the audit committee}

This refers to the number of people on the committee, which may be small or large (Dellaportas et al., 2012; Herdjiono \& Sari, 2017). Some studies recommend large size AC to be more effective because of increased resources (Rahmat et al., 2009) and the endowment of relevant diversity in views and expertise (Li et al., 2012). Others believe large AC size leads to process losses and diffusion of responsibilities, delay in its decision making (Karamanou and Vafeas, 2005; Adel and Maissa, 2013). Thus, market regulators and other CG codes have only provided for a minimum requirement on $\mathrm{AC}$ size to be three members, and this seemingly has become the convention (Bédard and Gendron, 2010; Samaha et al., 2015). In summary, to ensure effectiveness, the size of the AC should neither be too small nor too large. 


\subsubsection{Independence of audit committee}

Independence of audit committee implies the audit committee has separate membership from the executive board or is free from the influence and control of the executive board of the organization. To ensure effectiveness of the audit committee, it is required that the audit committee be independent of the executive board of the organization (Jun-Lin et al., 2008; Al-Matari 2013; Kallamu \& Saat 2015). Some studies contend that more NEDs on the AC enhance its independence and advocate strongly for the chairman of the committee to be also a NED (Cotter and Silvester, 2003; Hemraj, 2004; Barua et al., 2010).

\subsubsection{Expertise and experience of audit committee members}

This refers to the audit committee members' knowledge or experience in the field of auditing or finance. The members should have accounting and financial background and experience and have the capability to understand the issues being examined or discussed (McDaniel et al., 2002; Bedard et al., 2004). Other studies document that AC members' knowledge or expertise or experience in understanding corporate reporting and auditing issues is directly associated with the effectiveness of AC (Dhaliwal et al., 2010; Financial Reporting Council, 2012; Adel and Maissa, 2013).

Jun-Lin et al. (2008) argue that the audit committee's main task is to supervise corporate financial reporting and auditing processes, therefore, its members should have the capability to understand the issues being examined or discussed. DeFond et al. (2005) and Aldamen et al. (2012) indicated that an audit committee composed of directors with prior executive experience or financial knowledge is positively associated with company performance. The industry experience of directors may be more beneficial to a small company in its early stage of development, since the directors could serve as a management resource by providing a link to outside resources, such as contracts and connections. On the other hand, an established company in the declining stage of its development and with dispersed shareholders may benefit more from directors with technical or financial expertise who will concentrate on monitoring the company (Carcello and Neal 2003).

\subsubsection{Gender Diversity of Audit Committee}

Gender diversity of the committee means that the committee is neither all males nor all females, but a mixture of males and females since females have different perspectives and demand different information from men (Peni \& Vähämaa, 2010; Hameed \& Counsell, 2012; Alqatamin et al., 2017).

Feminist economists argue that women are more inclined to be neutral in moral judgements and behaviour than are men (Nelson 2012). Carter et al. (2003) reported that a significant relationship exists between the proportion of women on a board and the firm's performance. Erhardt et al. (2003) examined the relationship between gender diversity on the board and a company's financial performance among US companies. Their results indicate that the percentage of women on the boards of directors is positively associated with the firm's financial performance. Likewise, Campbell \& Mínguez-Vera (2008) investigating the effect of gender diversity on the boards of directors on firm financial performance, found a positive relationship. Miller \& del Carmen Triana (2009) examined the relationship between board diversity and company's performance. Their findings revealed that board diversity leads to enhanced organizational performance.

Similarly, Lückerath-Rovers (2013) found that the percentage of women on the board is positively and significantly related to company performance of Dutch companies. Lückerath-Rovers (2013) confirmed that firms with women directors performed better than those without women on their boards. However, Rose (2007) and Carter et al. (2010) found no relationship between the proportion of females on the board and company performance among Danish and US companies.

\subsubsection{Frequency of Meetings of the Audit Committee}

Frequency of meetings refers to the number of times the committee meets over a period of time. This is said to reflect the monitoring effectiveness of the committee (Xie et al., 2003; Lin et al., 2006), and that audit committees that meet more frequently are better informed about the organization's circumstances and provide a more effective oversight and monitoring mechanism of financial activities (Xie et al., 2003; Lin et al., 2006; AlMatari, 2013). Some are of the view that the AC should meet at least twice in a year and that the frequency of meeting activities of the AC ensures its effectiveness (Sharma et al., 2009; Zhang et al., 2007). However, the SEC Guidelines on AC in Ghana does not have any explicit provision on the number of meetings of AC, unlike other CG codes.

\subsection{Conceptual framework}

This study was conducted base on the conceptual framework below: 
Figure 3.1: Conceptual framework

\begin{tabular}{|c|c|}
\hline \multicolumn{2}{|l|}{$\begin{array}{l}\text { AUDIT COMMITTEE CHARACTERISTICS } \\
\text { Audit committee size }\left(\mathrm{H}_{1}\right)\end{array}$} \\
\hline Audit committee independence $\left(\mathrm{H}_{2}\right)$ & FINANCIAL \\
\hline Audit committee knowledge and experience $\left(\mathrm{H}_{3}\right)$ & PERFORMANCE: \\
\hline Audit committee gender diversity $\left(\mathrm{H}_{4}\right)$ & ROE \\
\hline
\end{tabular}

\subsubsection{Overview of the Concept of Performance}

Organizational performance is said to be probably the most widely used dependent variable in organizational research today. However, organizational performance is one of the vaguest and defined concepts (Rogers et al., 1998). It is observed that measuring organizational performance is difficult, especially when what has to be measured keeps changing (Hubbard, 2006).

Generally, organizational performance comprises the actual results or output of an organization as measured against its intended results or outputs. According to Venkatrman \& Ramanujam (1986) organizational performance has three dimensions: financial performance, operational performance, and stakeholder performance. Pierre et al. (2009) note that organizational performance encompasses three specific areas of firm outcomes: (a) Financial performance (profits, return on assets, return on investment, etc.); (b) Product market performance (sales, market share, etc.); and (c) Shareholder return (total shareholder return, economic value added, etc.). similarly, according to Shaker \& Basem (2010) organizational performance indicators from relationship marketing perspective include: increasing market share, retaining current customers, attracting new customers, creating loyal customers, increasing profit, increasing return on investment, and positive image.

Available literature on organizational performance indicate that the most common types of organizational performance measures used in recent empirical researches are financial or accounting performance, operational performance, and market-based performance (Combs et al., 2005; Brealey et al., 2001; Helfert, 1994; Higgins, 1995; Penman, 2001; Carton \& Hofer, 2006).

The current study uses financial performance to measure the organizational performance of the banks under study using two performance ratios namely return on assets (ROA) and return on equity (ROE). Generally, the current performance of banks in Ghana is found to be poor. Several banks have collapse over the last 5 years, for example UT Bank, Capital Bank, and GN Bank. Some observations about this poor performance of several banks in Ghana are that the banks have weak capacity to perform crucial financial reporting systems due to poor auditing. Glover-Akpey (2016) observed that fraudulent financial reporting has increased among the banking institutions in Ghana and this has made stakeholders at all level to become astounded.

\subsubsection{Audit committee and organizational performance}

Several available studies indicate with evidence that there is significant relationship between audit committee and organizational performance. However, whereas some studies found a positive relationship, others found a negative relationship. This section is a review of empirical studies on the impact of audit committee on organizational performance in general as well as the relationship between audit committee characteristics (i.e. audit committee size, independence of the committee, knowledge and experience of audit committee members and gender diversity of the audit committee) and organizational performance.

Based on several evidence-based data, it is widely acknowledged that effective audit committees enhance the performance of organizations. Some studies have shown that the functioning of audit committee enhanced the financial reporting quality and disclosure level of companies, especially where the audit committee met frequently (Soliman and Ragab, 2014; Bryan et al., 2004). However, Ebrahim (2007) and Xie et al., (2003) identified a negative relationship between frequency of audit committee meetings and firm performance.

Other studies such as Lin et al. (2006) and Baxter and Cotter (2009) identified no relationship between audit committee and performance of companies. They explained that fewer meetings organized by the audit committee members would be less committed and that there is inadequate time to deliberate and resolve important issues. Hence, the audit committee would not be able to perform their audit activities accordingly. Nevertheless, it is recorded that frequency meetings of audit committees are good indicator of predicting the financial performance of firms.

Madawaki and Amran (2013) mentioned that the size of audit committee affects the number of audit activities which influences financial performance of the companies. Xie et al. (2003), Soliman and Ragab (2014) and Abbott et al. (2004) found no significant relationship between the size of audit committee and earnings. According to Lin et al. (2006) the size of audit committees decreases earnings and financial management of companies. Baxter and Cotter (2009) argue that the larger the size of the audit committee the likelihood it can resolve potential financial 
problems which affect board decisions. This is due to the fact that more members in the committee indicate different expertise and knowledge and thus improving their audit performance and performance of the company as well. On the contrary, Karamanou and Vafeas (2005) argued that the larger the size of audit committee the more could face challenges regarding process losses and diffusion of responsibility. The literature provides mixed and inconclusive results on the relationship between audit committee variables and firm's performance.

The audit experience is also an important component of audit committee characteristics. Most available firms have interests in appointing at least an accounting and financial professional to form part of the audit committee membership. It is evidenced in literature that professionals or experts' representation in audit committee memberships improves effectiveness of their work (Soliman and Ragab (2014; Abbott et al., 2004; Xie et al., 2003).

Further studies such as DeFond et al. (2005) have provided evidence that markets react positively to the appointment of people who have financial and accounting skills to form part of audit committees. Madawaki and Amran (2013) added that experts on audit committees improve financial reporting quality and thus improving financial performance of a company. Nevertheless, Yang and Krishnan (2005) and Lin et al. (2006) had different views on audit committee experts and financial performance. According to the authors there are no relationship between audit committee experts and financial performance. Notwithstanding this, it is obvious to believe that audit committees with professionals or experts are capable of discussing and resolving important business issues in a more efficient and effective manner. They are also more likely to appoint independent and high-quality external auditor, which can generally improve audit quality.

Kikhia (2014) mentioned that audit committee with majority of outside directors provides an effective supervision. This is in turn, minimizes the internal control risk. According to Klein (2002) audit committee members should consist of independent officers so as to become effective. This is because independent audit committee helps to improve transparency of the company. It also reduces the possibility of earning management. Stanley (2011) added that composition of audit committee should make up of non-executive officers of which majority of them would be independent. Literature indicates that firms with fewer independent members on the audit committee experience fraud (Hat et al. 2006; Sottani, 2007; Baxter and Cotter, 2009).

In the view of Carcello and Neal (2000), a negative relationship exists between non-independent directors that form the audit committee and the number of times of audit meetings. In spite of this contradictory argument, it is noted that the independency of audit committee affect the extent of monitoring or supervision. This is due to the fact that the directors make objective decisions and demand less discussion therefore, the need for fewer meetings. Ismail et al. (2008) shared their views that audit committee independency do not affect the quality of reporting of firms because the company only fulfill its requirements.

The Blue Ribbon Committee (1999) report emphasized that independent audit committee monitors the financial reporting system in a more effective and efficient manner which therefore reduces the emergence of financial reporting challenges. In other words, to independent audit committee strengthens internal control systems of a firm. This is because audit committee enhances objectivity and protects the consistency of accounting process. In fact, audit committee independence has resulted to the minimization of intrinsic and control risks which lead to less practical challenging (Ismail et al. 2008). Consistent with the agency theory, it can be argued that audit committee independent encourages owners to supervise activities of managements and reduces the gains of preserved information. Supervision or monitoring activity becomes very effective in the presence of an independent audit committee. The reason is that an effective audit committee with independent officers' preserves the right and privileges of all stakeholders of the firm (Stanley, 2011).

\subsubsection{Audit committee size and performance}

Several studies indicate that there the size of an audit committee has impact on its effectiveness and thus the performance of the organization (Dellaportas et al., 2012; Herdjiono \& Sari, 2017). In the view of several management experts, for effectiveness in controlling and monitoring managers' behaviour, the audit committee must have enough members to carry out its responsibilities (Vicknair et al., 1993), with sufficient resources (Kalbers \& Fogarty 1993). However, the results from earlier studies on the relationship between audit committee size and company performance are not conclusive.

Pucheta-Martínez \& De Fuentes (2007) found that audit committee size affected the probability of companies receiving audit reports containing errors or non-compliant qualifications. Dalton et al. (1999) reported that audit committees become ineffective if they are either too small or too large. According to theme, an audit committee with many members tends to lose focus and become less participative than those of smaller size. On the other hand, an audit committee with a small number of members lacks diversity of skills and knowledge, and hence becomes ineffective. This means that, an audit committee of the right size would allow members to use their experience and expertise in the best interests of stakeholders.

Research by Menon \& Williams (1994) found a weak association between the size of the audit committee and organizational performance. However, Aldamen et al. (2012) concluded that smaller committees with more experience and financial expertise were positively and significantly associated with performance in the market. 
Similarly, Al-Matari (2013) found that audit committee size had a significant and positive relationship on the performance of the company he studied. This positive relationship is supported by resource dependence theory (Pearce \& Zahra 1992; Aldamen et al. 2012). According to this theory, the effectiveness of an audit committee increases when the size of the committee increases, because it has more resources with which to address the issues faced by the company. Thus, based on the dependence theory perspective, the following hypothesis is developed: $H_{1}$ : There is a positive relationship between size of an audit committee and organizational performance.

\subsubsection{Independence of the audit committee and performance}

To ensure effectiveness of the audit committee, it is required that the committee be independent of top management or the executive board of the organization (Jun-Lin et al., 2008). Although the findings of previous studies on this association are inconclusive, an independent audit committee does act better than a less independent committee, since the former is more likely to provide better monitoring through its ability to resist pressure from managers (Al-Matari 2013; Kallamu \& Saat 2015). It is argued that the independence of the audit committee from managers allows the committee to take an independent view of the financial reporting process of the company and ensure that the committee is not dominated by managers, leading to a higher audit quality (Peasnell et al., 2005; Kallamu \& Saat 2015). Audit committees chaired by independent directors are positively linked with high-quality financial reporting and a lower occurrence of fraudulent reporting (Akhigbe \& Martin, 2006; Nekhili et al., 2016). However, the independence of the audit committee chair may be of no use in enhancing the monitoring of management where the CEO is involved in the selection of directors (Carcello et al. 2011).

The independence of audit committee increases its strength, and reduces the agency problem and the opportunity for expropriation by insiders (Yeh et al., 2011). Independence makes the committee more objective in monitoring the transparency of financial reporting; a committee unbiased toward the executive thereby reduces the agency problem between executives and other shareholders. Chan \& Li (2008) found a positive relationship between the independence of the audit committee and organizational performance. Similarly, Kallamu \& Saat (2015) and Naimah (2017) found a positive association between independent audit committee members and profitability a proxy for organizational performance. Therefore, it is hypothesized that:

$\mathrm{H}_{2}$ : There is a positive relationship between an independent audit committee and organizational performance.

\subsubsection{Expertise and experience of audit committee members and performance}

The expertise (knowledge) and experience of audit committee members is an important feature that ensures the effectiveness of and audit committee. Several studies argue that audit committee members' knowledge or experience is directly associated with the committee's effectiveness (McDaniel et al., 2002; Bedard et al., 2004).

Jun-Lin et al. (2008) argued that the audit committee's main task is to supervise corporate financial reporting and auditing processes, therefore, its members should have the capability to understand the issues being examined or discussed. DeFond et al. (2005) and Aldamen et al. (2012) indicated that an audit committee composed of directors with prior executive experience or financial knowledge is positively associated with company performance. The industry experience of directors may be more beneficial to a small company in its early stage of development, since the directors could serve as a management resource by providing a link to outside resources, such as contracts and connections. On the other hand, an established company in the declining stage of its development and with dispersed shareholders may benefit more from directors with technical or financial expertise who will concentrate on monitoring the company (Carcello and Neal 2003). Hamid \& Aziz (2012) suggested that there is a positive and significant impact on organizational performance when the audit committee has directors with accounting and financial backgrounds. Therefore, it is hypothesized that:

$H_{3}$ : There is a positive relationship between audit committee members' knowledge and experience and organizational performance.

\subsubsection{Gender Diversity of Audit Committee and Performance}

It is argued that females have different perspectives and demand different information from men. Thus, it is claimed that gender is likely to have effect on organizational decisions (e.g. Peni \& Vähämaa, 2010; Hameed \& Counsell, 2012; Alqatamin et al., 2017).

Feminist economists argue that women are more inclined to be neutral in moral judgements and behaviour than are men (Nelson 2012). Carter et al. (2003) reported that a significant relationship exists between the proportion of women on a board and the firm's performance. Erhardt et al. (2003) examined the relationship between gender diversity on the board and a company's financial performance among US companies. Their results indicate that the percentage of women on the boards of directors is positively associated with the firm's financial performance. Likewise, Campbell \& Mínguez-Vera (2008) investigating the effect of gender diversity on the boards of directors on firm financial performance, found a positive relationship. Miller \& del Carmen Triana (2009) examined the relationship between board diversity and company's performance. Their findings revealed that board diversity leads to enhanced organizational performance.

Similarly, Lückerath-Rovers (2013) found that the percentage of women on the board is positively and significantly related to company performance of Dutch companies. Lückerath-Rovers (2013) confirmed that firms with women directors performed better than those without women on their boards. However, Rose (2007) and 
Carter et al. (2010) found no relationship between the proportion of females on the board and company performance among Danish and US companies. Therefore, it is hypothesized that:

$H_{4}$ : There is a positive relationship between gender diversity on the audit committee and organizational performance.

\subsection{Research Design}

This study employs the explanatory research design to analyze and explain the relationship between audit committee characteristics and the performance of listed banks in Ghana. Explanatory researches are usually conducted "to identify the relationships among variables when the research problem has already been narrowly defined" (Zikmund, 2003). Explanatory studies go beyond exploratory or descriptive studies to establish and explain the relationships between and among variables (Saunders et al., 2009). The data and method of analysis was purely quantitative. While the mean and standard deviation constitute the descriptive aspect of the analysis, Pearson's correlation as well as multiple regression analyses represent the inferential components. These enabled the researcher to better understand the relationship between audit committee characteristics and the financial performance of the listed banks on the GSE. A panel data analysis approach is employed for the evaluation of the effect of audit committee on the performance of the listed banks on the GSE. A panel data is a longitudinal or cross-sectional data in which entities are observed across time (Ahiawodzi \& Sackey, 2010).

Panel data regression is used to control certain overlooked uniqueness in individuals (Wooldridge, 2006) and to study dynamic changes in individuals (Gujarat, 2003). These are not achieved with cross-sectional data. Panel data regression is also used to address the coefficient biases which may be found in multiple regression by using fixed and random effect models (Gujarat, 2003, Wooldridge, 2006).

\subsection{Population of the Study}

A population is a complete group of entities sharing some common set of characteristics" (Zikmund, 2003, p. 369) and the population of relevance or target population is "the specific, complete group relevant to the research project" (Zikmund, 2003, p. 373). The population or unit of analysis for this study is banks listed on the Ghana Stock Exchange (GSE) as at the 2018 financial year. The study employed all the eight banks listed on the GSE. These banks are Access Bank Ghana Limited, Agricultural Development Bank (ADB), Cal Bank Ghana Limited, Ecobank Ghana Ltd, Ghana Commercial Bank, Republic Bank (Ghana) Ltd, Societe-Generale Ghana, Standard Charted Bank Ghana Ltd. The study focused on audit committee activities and fees of the banks - that is, how audit committee activities and audit fees affect performance of the banks. The data covered the audited financial statements and relevant reports of the banks for a period of five years ( 2014 to 2018).

\subsection{Sources and Method of Data Collection}

There are two main sources of data, being primary sources and the secondary sources. The primary sources are collected for a purpose and are also first-hand data while the secondary sources are those data that have already been gathered by others for other purposes and are available for use (Saunders et al., 2009). This study mainly used secondary data to analyze the impact of audit committee characteristics on the performance of the selected banks. The data was collected from annual reports and financial statements of the banks. The data collection was operationalized by manually extracting relevant data from the audited annual financial reports of the selected banks. Some of the audited annual financial reports were accessed by obtaining hard-copies directly from the companies, whereas others were downloaded from the official websites of the banks and the GSE.

\subsection{Description of Variables}

The study used Return on Equity (ROE) and Return on Assets (ROA) as the dependent variables which measure the financial performance of the companies. The independent variables include the audit committee characteristics which are size of the audit committee, independence of the committee, expertise and experience of audit committee members, gender diversity of the audit committee, and frequency of audit committee meetings.

\subsection{Validity and reliability}

Validity and reliability are important factors which should be the concern of every researcher while designing, analyzing results and judging the quality of the study (Patton, 2001). Reliability according to Joppe (2000) is the degree to which the data is consistent and gives accurate representation of the sample frame. If the results of a study can be replicated using a similar or the same methodology, then the research instrument is considered to be reliable. Validity on the other hand determines whether the research results truly measures that which it was intended to measure. In other words, data validity is the nearest to truthfulness of the outcome of the research (Joppe, 2000). This study achieved validity because the data was obtained from audited financial statements of the banks. 


\subsection{Data analysis}

\subsubsection{Relationship between audit committee characteristics and financial performance}

In other to ascertain if a relationship exists between audit committee characteristics and financial performance, a Pearson correlation of the two variables was run. The Pearson correlation matrix of the aforementioned variables is presented in Table 4.1

Table 4.1: Correlation between Performance and Audit Committee Characteristics

\begin{tabular}{|c|c|c|c|c|c|c|}
\hline & ROE & ROA & $\begin{array}{l}\text { Audit } \\
\text { commit } \\
\text { tee size }\end{array}$ & $\begin{array}{c}\text { Audit } \\
\text { committee } \\
\text { independen } \\
\text { ce }\end{array}$ & $\begin{array}{c}\text { Audit } \\
\text { Committee members' } \\
\text { expertise and } \\
\text { experience }\end{array}$ & $\begin{array}{c}\text { Gender diversity } \\
\text { of the audit } \\
\text { committee }\end{array}$ \\
\hline ROE & 1 & & & & & \\
\hline ROA & 0.899 & 1 & & & & \\
\hline Audit committee size & 0.511 & 0.803 & 1 & & & \\
\hline $\begin{array}{l}\text { Audit committee } \\
\text { independence }\end{array}$ & -0.126 & -0.481 & -0.570 & 1 & & \\
\hline $\begin{array}{l}\text { Audit Committee } \\
\text { members' expertise } \\
\text { and experience }\end{array}$ & 0.208 & 0.573 & 0.945 & -0.602 & 1 & \\
\hline $\begin{array}{l}\text { Gender diversity of } \\
\text { the audit committee }\end{array}$ & -0.050 & -0.256 & -0.641 & -0.014 & -0.707 & 1 \\
\hline
\end{tabular}

\subsubsection{Discussion of results}

Table 4.1 above shows that there is a fairly strong positive correlation between the audit committee size and the return on equity $(\mathrm{r}=0.511)$. However, there is a strongly positive correlation between audit committee size and return on asset $(\mathrm{r}=0.803)$. This finding agrees with studies conducted by Dellaportas et al. (2012) and Herdjiono \& Sari (2017) who opined that there exists a positive relationship between the size of the audit committee and organizational performance. This characteristic is closely related with the expertise of the committee. Thus, the larger the size of the committee the more the diversity of knowledge possessed by expertise working on the committee (Pearce \& Zahra 1992; Aldamen et al. 2012). A strongly positive association ( $\mathrm{r}=0.95)$ between the size of the audit committee and the expertise and experience of the committee from the correlation matrix supports the fact that the banks' audit committee size meets the set standard.

On the expertise and experience of audit committee members, there was a weak positive correlation with return on equity $(\mathrm{r}=0.208)$ but a fairly strong association with return on asset $(0.573)$. This finding is supported by studies conducted by McDaniel et al. (2002) and Bedard et al. (2004) who found that the knowledge possessed by the audit committee member is directly correlated with the effectiveness of the committee and hence the organization's performance.

However, audit committee independence correlated weakly with both return on equity and return on asset $(\mathrm{r}=-0.126,-0.481)$. Also, gender diversity of the audit committee had a weak negative correlation with both return on asset and return on equity $(\mathrm{r}=-0.050,-0.256)$. The findings above are contrary previous research conducted by Al-Matari (2013) and Kallamu \& Saat (2015) who indicated that an independent audit committee does act better than a less independent committee, since the former is more likely to provide better monitoring through its ability to resist pressure from mangers.

More so, Peni \& Vähämaa (2010), Hameed \& Counsell (2012) and Alqatamin et al. (2017) argued that females have different perspectives and demand different information from. Thus, it is claimed that gender is likely to have an effect on organizational decisions. The difference in the outcome of these studies might be alluded to the fact that the period (2014-2018) during which the present study was conducted was saw a falling trend in the general performance of the Ghanaian banking sector.

During that period, general corporate governance practices for a number of banks were not adhered to and corporate governance structure, in some instances, was sidelined. This led to a loss in investors' capital, purchase and acquisition of weaker banks and a recapitalisation drive by the industry's regulator - the bank of Ghana (Bank of Ghana, 2017). Hence, the negative correlation observed between audit independence and gender diversity as against organizational performance, can be attributed to external factors which were beyond the composition and structure of the audit committee.

\subsection{Conclusion}

The function and activities of the audit committee are crucial to the success of any organization anywhere. These effects can be seen the financial performance of these banks over the period and trickles down to the overall performance of the banking sector. A weak independence of the audit committee has serious implications for the financial performance of the banks. These results are not limited to the banking sector alone but they can be 
extended to other companies and the economy as a whole. From the findings of the study, one can conclude that audit size and the expertise and experience of members of a banks audit committee can positively influence the performance of banks listed on the Ghana Stock Exchange

\subsection{Recommendations}

Based on the findings of the study, recommended that management of banks should ensure that the best corporate governance practices, with respect to audit, must be adhered to.

Policy makers and regulators of financial institutions should also ensure that management of the banks are supervised and regulated to implement quality metrics as this would enhance the performance of the banks.

Unlisted banks and other corporate originations should be included in further studies so that that the findings can be generalized for all companies that have audit.

\section{References}

Abbott, L. J., Parker, S., and Peter, G.F. (2004). Audit committee characteristics and restatement. Auditing: Journal of Practice and Theory, 23(1), 69-87.

Afify, H. (2009). Determinants of audit report lag: Does implementing corporate governance have any impact? Empirical evidence from Egypt. Journal of Applied Accounting Research, 10(1), 56-86.

Aldamen, H., K. Duncan, S. Kelly, R. McNamara, \& S. Nagel. (2012). Audit committee characteristics and firm performance during the global financial crisis. Accounting \& Finance, 52(4), 971-1000.

Al-Matari, Y.A. (2013). Board of Directors, Audit Committee Characteristics and Performance of Saudi Arabia Listed Companies. International Review of Management and Marketing, 2(4), 241-251.

Al-Thuneibat A (2006) Audit in the light of the international auditing standards and regulations and local laws: the theory and application. Amman, Jordan University publications.

Amer, M., Ragab, A.A., and Shehata, E.S. (2014). Audit Committee Characteristics and Firm Performance: Evidence from Egyptian Listed Companies. Proceedings of 6th Annual American Business Research Conference, 9 - 10, Sheraton LaGuardia East Hotel, New York, USA.

Arens A.A, Elder, R.J, and Beasley, M.S. (2014). Auditing and Assurance Services: An Integrated Approach. Pearson Education Ltd.

Carcello, J. V., and Neal, T.L. (2005). Audit committee characteristics and auditor dismissals following "new" going-concern reports. The Accounting Review, 78(1), 95-117. https://doi.org/10.2308/accr.2003.78.1.95

Campbell, K., \& A. Mínguez-Vera. (2008). Gender diversity in the boardroom and firm financial performance. Journal of Business Ethics, 83(3), 435-451. https://doi.org/10.1007/s10551-007-9630-y

Collier, P. (1993). Audit committees in major UK companies. Managerial Auditing Journal, 8(3), 25-31. http://dx.doi.org/10.1108/02686909310036241

Contessotto, C., and Moroney, R. (2014). The association between audit committee effectiveness and audit risk. Accounting \& Finance, 54(2), 393-418. https://doi.org/10.1111/acfi.12010

Bank of Ghana. (2017). State of the Financial Sector in Ghana. Accra, Ghana. Retrieved from https://www.bog.gov.gh/privatecontent/Public_Notices/State of the Banking System.pdf

DeFond, M. L, R. N. Hann, and X. Hu. (2005). Does the market value financial expertise on audit committees of boards of directors? Journal of Accounting Research 43 (2): 153-193.

Ghazali, Anum, M. N. (2010). Ownership structure, corporate governance and corporate performance in Malaysia. International Journal of Commerce and Management, 20(2),109-119. https://doi.org/10.1108/10569211011057245

Glover-Akpey, I., Azembila, A.B., (2016). The Effect of Audit Committees on the Performance of Firms Listed on the Ghana Stock Exchange. Journal of Business and Management, 18(11), 55-62.

Gujarat, D. N. (2003). Basic Econometric. (4th International edn.) USA: McGraw-Hill.

Kallamu, B. S., \& N. A. M. Saat. (2015). Audit committee attributes and firm performance: evidence from Malaysian finance companies. Asian Review of Accounting, 23(3), 206-231. https://doi.org/10.1108/ARA11-2013-0076

Lin, J., Li, J., and Yang, J. (2006). The effect of audit committee performance on earnings quality. Managerial Auditing Journal, 21(9): 921-933.

Mitra, S., Hossain, M., Deis, D.R., (2007). The empirical relationship between owner-ship characteristics and audit fees. Review of Quantitative Finance \& Accounting 28 (3), 257-285.

Penrose, E. T., (1959). The Theory of the Growth of the Firm, Oxford: Basil Blackwell.

Preuss, L. (2013). Buying into our future: sustainable initiatives in local government procurement. Business Strategy and the Environment 16, 354-365.

Rezaee, Z. (2009). Corporate Governance and Ethics. United States: John Wiley \& Sons.

Rustam, S., Rashid, Zaman, K. (2013). The relationship between audit committees, compensation incentives and corporate audit fees in Pakistan. Economic Modeling, 31, 697-716. 
Saunders, M., Lewis, P. \& Thornhill, A. (2009). Research Methods for Business Students (5th edn). Edinburgh: Prentice Hall.

Sebe-Yeboah, G. \& Mensah, C. (2014). A Critical Analysis of Financial Performance of Agricultural Development Bank (ADB, Ghana). European Journal of Accounting Auditing and Finance Research, 2(1), 11-23.

Tate et al., W. T. (2010). Corporate social responsibility reports: a thematic analysis related to supply chain management. J. Supply Chain Management, 46 (10), 19-44.

Soliman, M. M., and A. A. Ragab. (2014). Audit committee effectiveness, audit quality and earnings management: an empirical study of the listed companies in Egypt. Research Journal of Finance and Accounting 5 (2): 155 166.

Verschoor, C.C. (2008). Audit Committee Essentials. John Wiley \& Sons.

Wooldridge, J. M. (2006) Introductory Econometric: A Modern Approach. International Student edition, 3e, Canada: Thomson South-Western.

Xiel, B., Davidson. W., and DaDalt, P. (2003). Earnings management and corporate governance: the roles of the board and the audit committee. Journal of Corporate Finance 9 (3): 295-317.

Zikmund, W.G. (2003). Business Research Method, (7th edn.). Cengage Learning, In 